\title{
Regulering av immunrespons mot virus
}

\section{Antigenspesifikke undergrupper av T-celler samarbeider for \\ å bekjempe virusinfeksjoner.}

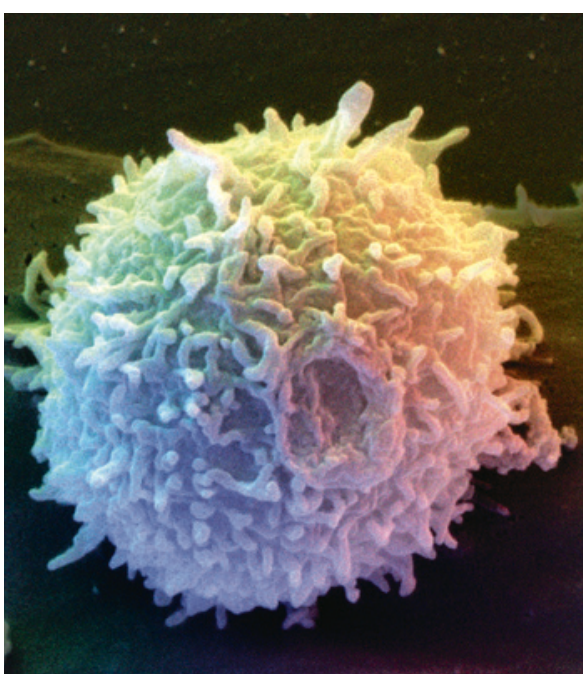

Illustrasjonsfoto Science Photo/NTB scanpix
Ved kroniske virusinfeksjoner blir immunresponsen ofte ineffektiv, med «utslitte» og kortlivede immunceller. Immunsystemet prøver å kompensere dette med økt regenerasjon av antigenspesifikke lymfocytter, men reguleringsmekanismene er bare delvis forstått.

I en studie med mus infisert med lymfocyttisk koriomeningitt-virus (LCMV) fant amerikanske forskere to transkripsjonsfaktorer med motsatte effekter på CD8-positive T-celler (1). Begge faktorene var avgjørende for å opprettholde en balansert pool av LCMVspesifikke T-celler, men en av dem var overuttrykt i «utslitte» CD8-positive LCMV-spesifikke drepeceller, som hadde flere inhibitoriske reseptorer for immunaktivering.

- Denne studien gir økt innsikt som kan gi nye terapeutiske muligheter ved kroniske virusinfeksjoner, sier professor Dag Kvale ved Infeksjonsmedisinsk avdeling, Oslo universitetssykehus. - LCMV-infeksjon hos mus brukes mye som immunologisk modell for utvikling av kroniske infeksjoner, sier han.

- Vi gjennomførte nylig en klinisk randomisert studie ved kronisk hivinfeksjon med antiinflammatoriske legemidler (cyklooksygenasehemmere), som primært regulerer andre intracellulære signalveier, nemlig cAMP (2). Påvirkning av disse signalveiene reduserte noen av de samme reseptorene på hivspesifikke CD8-positive T-celler, samtidig med forbedret immunsvar etter vaksinering. Målet er å utvikle strategier for behandling som kan bedre immunresponsen mot kroniske virusinfeksjoner og som kan erstatte dagens behandling, som er kostbar og bare tilgjengelig i rike land, sier Kvale.

\section{Trine B. Haugen}

trine.b.haugen@hioa.no

Tidsskriftet

\section{Litteratur}

1. Paley MA, Kroy DC, Odorizzi PM et al. Progenitor and terminal subsets of CD8+ T cells cooperate to contain chronic viral infection. Science 2012; 338: $1220-5$.

2. Pettersen FO, Torheim EA, Dahm AE et al. An exploratory trial of cyclooxygenase type 2 inhibitor in HIV-1 infection: downregulated immune activation and improved $T$ cell-dependent vaccine responses. J Virol 2011; 85: 6557-66.

\section{Varmere vær gir økt risiko for hjerteinfarkt}

\section{Utendørstemperaturer over $20{ }^{\circ} \mathrm{C}$ innebærer $ø$ kt risiko for hjerteinfarkt de første seks timene etter temperaturstigning.}

Høy temperatur utendørs er assosiert med økt korttidsdødelighet, men det er uklart om dette kan knyttes til økt risiko for hjerteinfarkt. I de fleste studier er det forskjeller i dagtemperaturer som er målt. Britiske forskere har nå sett på effekten av varme på risikoen for hjerteinfarkt ved å bruke temperatur målt hver time (1).

Rundt 25000 innleggelser for hjerteinfarkt $i$ juni, juli og august $i$ årene 2003-09 ble sammenholdt med temperaturmålinger fra samme periode. Resultatene viste effekt av oppvarming 1-6 timer etter eksponering for temperaturer over en estimert terskel på $20{ }^{\circ} \mathrm{C}$. For hver grad over $20^{\circ} \mathrm{C}$ økte risikoen for hjerteinfarkt med 1,9\% $(\mathrm{p}=0,009)$. Den kumulative effekten av en økning på $1{ }^{\circ} \mathrm{C}$ over terskelverdien var borte på slutten av den tredje dagen etter eksponering.

- Dette er en imponerende studie med nyttige resultater, sier overlege Henrik Schirmer ved Hjertemedisinsk avdeling, Universitetssykehuset Nord-Norge. - Risikoen er ikke økt på varme dager, men den er knyttet til selve økningen når temperaturen overstiger $20{ }^{\circ} \mathrm{C}$, sier han

- Varmeøkningen utløser sykdom tidligere enn det ellers ville ha skjedd hos personer med ustabile plakk, som på forhånd har høy risiko for hjerteinfarkt. Dette ser man ved at risikoøkningen totalt sett er null etter tre dager. Risikoen gjelder i hovedsak de alvorlige transmurale infarktene, hvor den de første 1-6 timene er på hele $2,7 \%$. Ved en temperaturstigning på $15^{\circ} \mathrm{C}$ over $20^{\circ} \mathrm{C}$ er risikoøkningen ca. $40 \%$. Dette er nyttig å ha i mente for høyrisikopersoner på sydentur, sier Schirmer. - Årsaken er trolig væsketap og økt belastning på hjertet pga. økt blodtilførsel til huden for nedkjøling.

\section{Trine B. Haugen}

trine.b.haugen@hioa.no

Tidsskriftet

\section{Litteratur}

1. Bhaskaran K, Armstrong B, Hajat S et al. Heat and crossover analysis of MINAP database. BMJ 2012; 345: e8050. risk of myocardial infarction: hourly level case-

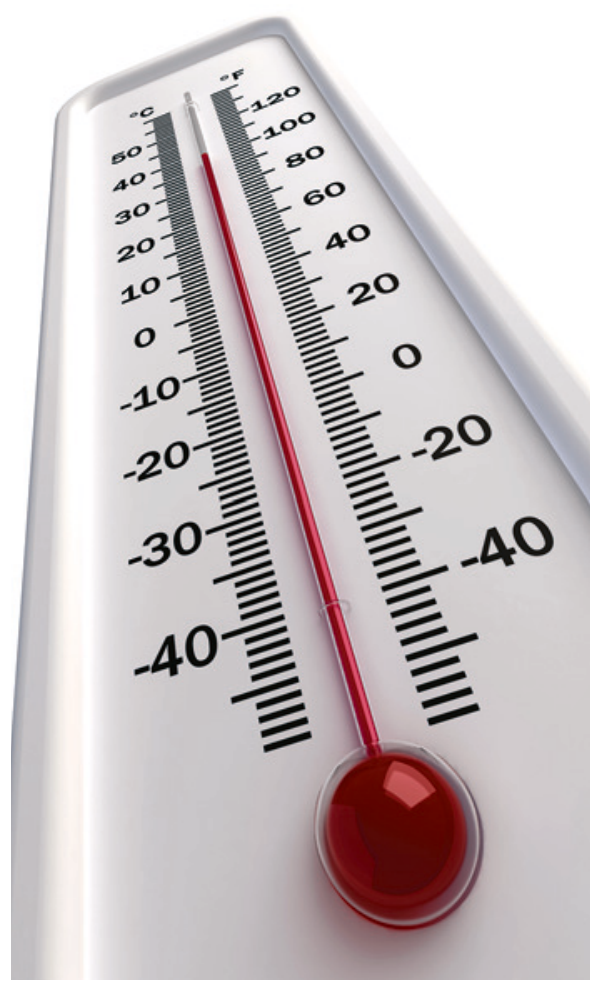

Illustrasjonsfoto thinkstock 